\title{
Laterality of muscle thickness in athletes who perform throwing and hitting motions
}

\author{
Shin Hasegawa and Kyotaro Funatsu \\ 九州共立大学スポーツ学部, † 807-8585 福岡県北九州市八幡西区自由ヶ 丘 1-8 (Faculty of Sports Science, Kyushu Kyoritsu \\ University, 1-8 Jiyugaoka, Yahatanisi-ku, Kitakyushu-shi, Fukuoka 807-8585, Japan)
}

Received: December 15,2012 / Accepted: April 24, 2013

\begin{abstract}
The present study investigates the laterality of muscle thickness (MT) in athletes who perform throwing and hitting motions. Sixty right-handed college athletes (baseball pitchers group, PG; tennis players group, TG; baseball batters group, BG and controls group, CG; all $\mathrm{n}=15$ ) participated in this study. Muscle thickness was measured by B-mode ultrasound at the forearm, anterior and posterior upper arm, subscapula, chest, abdomen, lateral abdomen, anterior and posterior thigh and anterior and posterior lower leg. Muscle thickness in the dominant forearm, subscapula, and chest in PG, forearm, chest, anterior and posterior upper arm in TG and the subscapula and chest in BG were significantly larger than those in the non-dominant side. On the other hand, the MT in the non-dominant lateral abdomen in PG, the abdomen and lateral abdomen in TG, and the posterior upper arm and lateral abdomen in BG were significantly larger than those in the dominant side. The ratio of dominant to non-dominant MT was significantly smaller for the internal oblique muscle and total thickness of lateral abdomen in PG, TG and BG than CG. Laterality of the internal oblique muscle and total thickness of lateral abdomen in the non-dominant side is a common characteristic of athletes who perform throwing and hitting motions.
\end{abstract}

Jpn J Phys Fitness Sports Med, 62(3): 227-235 (2013)

Keywords : muscle thickness, laterality, ultrasound

\section{緒言}

人体は正中矢状断によって左右ほぼ等しい両半に分け ることができ, 左右対称的であるが1)，四肢では利き手 や利き足に形態的, 機能的な一側優位性が見られること が知られている 利き側の運動様式, 使用頻度が異なる動作を繰り返し行 う競技者の場合, 身体に顕著な機能的, 形態的な一側優 位性が示される，例えば，機能面における一側優位性と しては, 野球, テニス, バレーボール選手の肩関節の内 旋筋力や水平内転筋力, 肘関節の屈曲筋力や伸展筋力, 前腕の回内筋力, 手関節の掌屈筋力は, 利き側が非利き 側との比較において同等以上の值を示し, 右投右打の野 球選手の体幹回旋筋力は左回りの方が高い值を示す ${ }^{3-12)}$. 一方, 形態面における一側優位性としては, 野球, 陸上 投擲など投動作を伴う競技者の前腕部, 上腕部, 肩部, 胸部では，利き側が非利き側よりも大きな筋量を示し， 腹部, 背部, 大腿部では, 非利き側が利き側よりも大き
な筋量を示す ${ }^{13-18)}$ 。また，テニス，バレーボール，バド ミントンなど打動作を伴う競技者でも腕部, 体幹部, 大 腿部に関する部位別の研究が見られるが, 前腕部, 上腕 部, 肩部では利き側が非利き側に対して大きな筋量を示 すこと, 腹部や腰部では非利き側が利き側に対して大き な筋量を示すことが報告されている ${ }^{19-26)}$.

運動学的には，投動作は「手に持っている物体に，手 によって速度を与えて空中に放す」動作，打動作は「道 具を含めたからだの端を効果器とし, 衝撃力を大きくす るためにそれを加速し，ボールあるいはヒトといった対 象物にその衝撃力を与える」動作として，区分されてい る27,28). しかし, 投動作や打動作はいずれも下肢から上 肢へと力を伝達する運動連鎖を伴い，体幹における捻転 が重要な役割を果たしており ${ }^{29)}$, 筋電図学的研究からも ボール投げ，バレーボールのスパイク，バドミントンの スマッシュ，テニスのサーブなどオーバーヘッド型の投 動作や打動作における体幹や上肢の筋放電パターンには 類似性があることが報告されている30)。また，宮西ら ${ }^{31)}$ 
も野球の投動作と打動作について，下胴が主導的な役割 を果たし，その回転が上胴の回転に先行することで体幹 が逆方向へ捻られた後, 捻り戻されて上胴が回転する点 において共通性がみられるとしている。一方，同じ打動 作でも，テニスのサーブやフォアハンドストロークのよ うな片腕で行われる動作と, 野球のバッティングのよう な両腕を用いる動作における筋活動を示す部位のちがい や，バッティングにおける両腕の同名筋の筋活動のタイ ミングや大きさのちがいなど28,32)，「手」や「打具」を 動かす腕の動作には特異性がみられることが報告されて いる.

これまでの先行研究は, 投動作や打動作には動作特異 的な相違点もあるものの, 両動作には共通した特徵が見 られ，これらが競技者の一側優位性に影響している可能 性を示唆している。投動作を伴う競技者を対象とした， 全身の筋厚や筋断面積の一側優位性に関する研究はいく つか見られるが14,15,17)，打動作を伴う競技者を対象とし た同様の研究は行われていない. また, 先行研究では利 き側の影響による一側優位性と，競技動作を反復するこ とによって生じる一側優位性のちがいについては明らか にされていない，そこで本研究では，投動作や打動作を 伴う競技者である野球投手，テニス選手，野球打者にお ける筋厚の一側優位性が示される部位，掞よびその大き さを比較することにより，これらの競技者にみられる上 肢，体幹，下肢に扔ける筋発達の特性㧍よびその共通性 を明らかにすることを目的とした。

\section{方 法}

被験者 被験者は男子大学生スポーツ選手60名であり， その内訳は投動作を伴う競技者として野球投手15名（以 下野球投手, PG: baseball pitchers group), 主に片腕で の打動作を伴う競技者として大学生テニス選手15名（以 下テニス選手, TG: tennis players group), 両腕での打 動作を伴う競技者として大学生野球選手 (野手) 15名 (以 下, 野球打者, BG: baseball batters group), 投動作や打 動作を伴わない短距離種目を専門とする陸上競技選手 15 名 (以下対照群, CG: controls group)であった(Table 1). 被験者は全員が右利きであり，野球投手，野球打者は
右投げ右打ち, テニス選手はサーブを右腕で打つ者とし, いずれも主たる投動作や打動作が鉛直軸の上方から見て 左回りの回旋動作となる競技者とした。野球投手，テニ 又選手，野球打者は過去の運動歴において他の投動作や 打動作を伴う競技は実施しておらず，対照群については 過去に投動作や打動作を伴う運動歴も持たない者とし た。 また，野球投手は中学生以降の競技歴において投手 を専門に行ってきた者であり，大学入学後の練習におい て打撃練習は行っていない. 野球打者は中学生以降の競 技歴において投手経験のある者を除外した。野球投手, テニス選手，野球打者，対照群は日常的にレジスタンス トレーニングを実施していた。 トレーニングプログラム は所属団体で統一されたものではなく，それぞれが異な るものであったが，いずれも利き腕と非利き腕の負荷強 度や反復回数を意図的に変える等の片側性の筋力発揮を 強調するトレーニングを含むものではなかった．

被験者には，あらかじめ研究の目的，方法，実験に伴 う安全性を説明し，書面にて実験参加の同意を得た。な 扮，本研究は九州共立大学倫理委員会の承認を得て実施 した

形態測定 形態測定の項目は身長，体重，上腕長，前腕 長，手長，大腿長，下腿長，上腕囲，前腕囲，大腿囲， 下腿囲の 11 項目であった。身長は身長計を用いて $0.1 \mathrm{~cm}$ 単位まで測定した。体肢長はマルチン式計測器を用い, 測定点間の距離を $0.1 \mathrm{~cm}$ 単位で測定した。 上腕長は肩峰 から上腕骨外側上顆まで，前腕長は橈骨頭から尺骨茎状 突起まで, 手長は尺骨茎状突起から中指先端までとした。 また，大腿長は大転子点から脛骨外側果まで，下腿長は 脛骨外側果から腓骨外果までとした，周径囲は布製のメ ジャーを用い，測定点間の距離を $0.1 \mathrm{~cm}$ 単位で測定した。 測定はいずれも立位で行い，上腕囲は上腕長の近位から $60 \%$ ，前腕囲は前腕長の近位から 30\%，大腿囲は大腿長 の近位から 50\%, 下腿囲は下腿長の近位から 30\%の部位 にて，利き側（D：Dominant）と非利き側（ND：Nondominant）の両側について実施した。

筋厚測定 筋厚測定には B モード超音波診断装置 (SSD-

Table 1. Physical characteristics of subjects.

\begin{tabular}{lrrrr}
\hline Variables & \multicolumn{1}{c}{ PG } & TG & BG & CG \\
\hline Age (y) & $19.0 \pm 0.8$ & $19.3 \pm 1.5$ & $19.7 \pm 0.8$ & $20.0 \pm 1.0$ \\
Height (cm) & $177.0 \pm 6.7{ }^{*}$ & $171.3 \pm 5.5$ & $173.7 \pm 4.4$ & $173.7 \pm 4.4$ \\
Body mass (kg) & $74.7 \pm 6.5^{* \#}$ & $58.9 \pm 7.4$ & $74.2 \pm 6.7{ }^{*}$ & $64.3 \pm 5.6$ \\
Duration of playing (y) & $10.8 \pm 1.8^{* \#}$ & $6.7 \pm 2.2$ & $11.5 \pm 1.6{ }^{* \#}$ & $7.8 \pm 2.8$ \\
\hline
\end{tabular}

Means \pm SD. PG, Pitchers; TG, Tennis players; BG, Batters. CG, Controls. ${ }^{*} \mathrm{p}<0.05$, Significantly different from TG. \#p $<0.05$, Significantly different from CG. 
900, アロカ社製）および7.5MHzのリニア式プローブを 用い, 利き側と非利き側の前腕部, 上腕前部, 上腕後部, 大腿前部，大腿後部，下腿前部，下腿後部，肩甲下部， 胸部，前腹部，側腹部の11部位を測定した（Fig. 1）.

上肢，下肢㧍よび肩甲下部の測定はAbe et $\mathrm{al}^{33}{ }^{33}$ の方 法に基づき立位で行った。前腕部は前腕長の近位から $30 \%$ ，上腕前部，上腕後部は上腕長の近位から $60 \%$, 大 腿前部, 大腿後部は大腿長の近位から $50 \%$, 下腿前部, 下腿後部では下腿長の近位から $30 \%$ ，肩甲下部は肩甲骨 下角の $5 \mathrm{~cm}$ 下方を測定部位とした。胸部は島野ら ${ }^{17)}$ の 方法に基づき仰臥位で行った，肩峰点と胸骨上点の中間 位㧍よび胸骨上点と胸骨中点の中間位の交点位置を測定 部位とした。前腹部, 側腹部は久保田ら ${ }^{21)} の$ 方法に基づ き仰臥位で行った，前腹部は腱画により左右それぞれ 4 つに分けられる腹直筋の筋腹の上から 3 番目 (第 3 筋腹) において白線と外側縁の中間位, 側腹部は胁骨と上前腸 骨棘との中間を測定部位とし，筋厚に対する呼吸の影響 を小さくするため呼気終末時に撮影を行った．

撮影した超音波画像は医療用レコーダー（メディキャ プチャーUSB-200, NET-JAPAN）を介して画像ファ イルとして取得した後, 画像解析ソフト (Scion Image, Scion Corporation）を用いて筋厚を測定した．筋厚は前 腕部, 上腕前部, 上腕後部, 大腿前部, 大腿後部, 下腿 前部, 下腿後部, 肩甲下部についてはAbe et $\mathrm{al}^{33)}$ の方法,

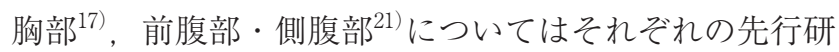

究の方法を用いて測定し，側腹部については側腹筋 ${ }^{1)}$ 構成する外腹斜筋，内腹斜筋，腹横筋の筋厚の測定も同 時に実施した。

筋厚の測定は 1 名の検者が実施し, 事前に 3 名の被験 者を対象に10回の超音波撮影を行い, 各部の筋厚を求め たところ，その変動係数はいずれの部位においても $2 \%$ 以下であった。

統計処理 測定值は全て平均值士標準偏差で示した。被 験者の身体特性に関する比較には，一元配置の分散分析 を行い，有意性が認められた場合には，Tukey法による 多重比較を行った。

利き側と非利き側の筋厚の比較については，対応のあ る $\mathrm{t}$ 検定を用いた。 また, 筋厚の一側優位性の大きさは, 非利き側に対する利き側の比率 $(\mathrm{D} / \mathrm{ND}$ 比率 $=$ Dominant $/$ Non-dominant $\times 100 ）$ として表した. 同比率の $100 \%$ は利 き側と非利き側が同等であること，100\%よりも大きい 值は利き側が優位であること，100\%よりも小さい值は 非利き側が優位であることを示す，利き側の影響によ る $\mathrm{D} / \mathrm{ND}$ 比率と投動作や打動作を反復することにより見 られる D/ND比率を比較するため, 部位別に一元配置の 分散分析を用い，対照群を基準としたDunnett法による 多重比較を行った、いずれも統計的な有意水準は $\mathrm{p}<0.05$ とした。
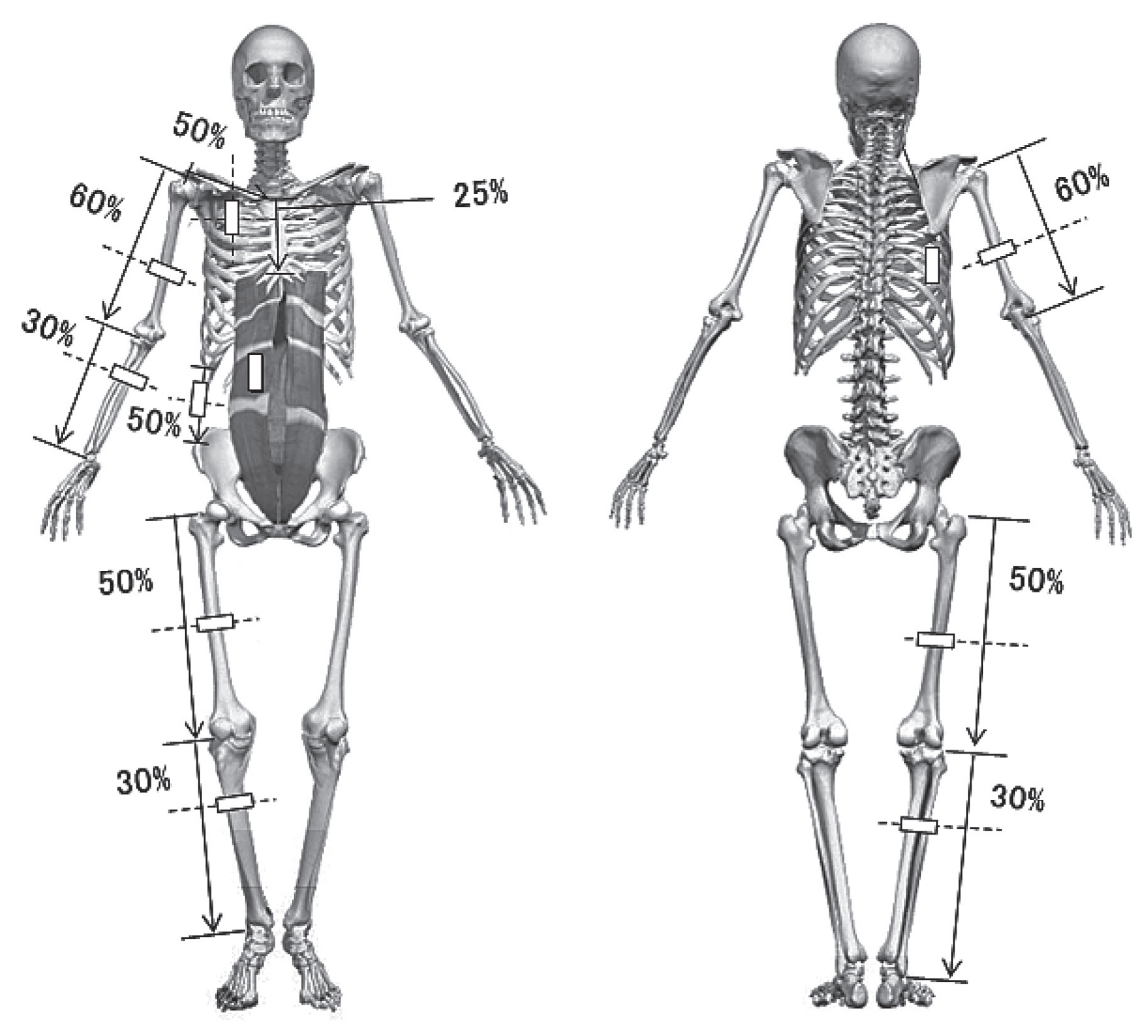

Fig. 1 Sites of muscle thickness measurements. 


\section{結 果}

利き側と非利き側の一側優位性 形態測定における上肢 と下肢の長径と周径囲をTable 2 に示した。対照群の上 腕囲, 前腕囲では利き側が高い值を示したが, その他の 指標では利き側と非利き側の差は示されなかった.一方, 野球投手の前腕囲, テニス選手の上腕囲と前腕囲, 野球 打者の下腿囲では, 利き側が非利き側に対して有意に高 い值を示した。

筋厚測定における各測定部位の筋厚をTable 3 に示し た，対照群では11部位の全てにおいて，利き側と非利き 側の間に差は示されなかった。一方, 野球投手の前腕部, 肩甲下部, 胸部, テニス選手の前腕部, 上腕前部, 上腕 後部, 胸部, 野球打者の肩甲下部, 胸部では, 利き側が 非利き側に対して有意に高い值を示し, 野球投手群の側 腹部, テニス選手の前腹部, 側腹部, 野球打者群の上腕 後部，側腹部では，非利き側が利き側に対して有意に高 い值を示した。また, 側腹部を構成する内腹斜筋では野 球投手，テニス選手，野球打者において，非利き側が利 き側に対して有意に高い值を示し, 腹横筋ではテニス選 手と野球打者, 外腹斜筋ではテニス選手において, 非利 き側が利き側に対して有意に高い值を示した。一方，下 肢の大腿前部, 大腿後部, 下腿前部, 下腿後部の筋厚で は,いずれの群においても両側間の差は示されなかった。

一側優位性の大きさ 投動作や打動作を伴う競技者であ る野球投手, テニス選手, 野球打者と対照群との D/ND 比率をFig. 2 に示した。対照群では全ての部位の D/ND 比率は 98.8\% (大腿前部) 〜 105.7\% (上腕後部) の範囲 であった。野球投手, テニス選手, 野球打者と対照群の
比較において，上肢では，テニス選手の前腕部（110.0土 8.7\%）が対照群よりも有意に高い值を示し，野球打者の 上腕後部 $(92.6 \pm 12.9 \%)$ が対照群よりも有意に低い值 を示した。 また, 体幹部では, 野球投手の肩甲下部 (113.2

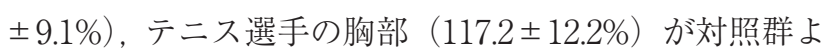
りも有意に高い值を示し, テニス選手の前腹部 (91.7 7.9\%), 野球投手, テニス選手, 野球打者の側腹部（PG：

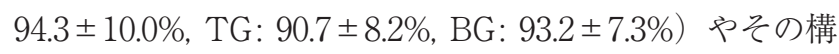
成筋である内腹斜筋（PG: $91.7 \pm 12.4 \%, T G: 89.5 \pm 9.2 \%$, BG: $91.4 \pm 8.7 \%)$ が対照群よりも有意に低い值を示した. 一方，下肢では，野球投手，テニス選手，野球打者の全 ての測定部位において対照群との差は示されなかった。

\section{考察}

ヒトの四肢では，日常生活で頻繁に使用する利き側の 前腕囲や上腕囲には, 形態的な優位性が見られるが, 一般 成人の上肢において, 利き側と非利き側の間には筋厚や 筋断面積の差が示されないことが報告されている X線画像の分析から, 四肢における組織の横断面積の非 対称性は皮下脂肪, 骨, 筋の順番に大きいことが報告さ れており 2), 周径囲の非対称性には筋以外の組織, 特に皮 下脂肪の影響が強く反映されることが示唆されている. そこで本研究では, 筋厚のみに着目して投動作や打動作 を伴う競技者の一側優位性について論じるものとする。

筋厚測定の結果から，対側に対する筋厚の優位性が見 られた部位をFig. 3 に概念図として示した。 上肢では対 照群の前腕部, 上腕前部, 上腕後部の筋厚に両側間の差 は示されなかった，本研究の対照群は陸上短距離選手で あり，利き側のみを頻繁に使用する競技者ではない。こ のため, 先行研究における一般成人 ${ }^{2,13,14)}$ の場合と同様

Table 2. Comparison of length and girth between dominant and non-dominant sides.

\begin{tabular}{|c|c|c|c|c|c|c|c|c|}
\hline & \multicolumn{2}{|c|}{$\mathrm{PG}$} & \multicolumn{2}{|c|}{ TG } & \multicolumn{2}{|c|}{$\mathrm{BG}$} & \multicolumn{2}{|c|}{$\mathrm{CG}$} \\
\hline & $\mathrm{D}$ & ND & $\mathrm{D}$ & ND & $\mathrm{D}$ & ND & $\mathrm{D}$ & $\mathrm{ND}$ \\
\hline \multicolumn{9}{|l|}{ Length $(\mathrm{cm})$} \\
\hline Upper arm & $32.8 \pm 1.9$ & $32.9 \pm 1.8$ & $31.2 \pm 1.5$ & $31.1 \pm 1.5$ & $31.8 \pm 1.4$ & $31.9 \pm 1.2$ & $32.0 \pm 0.9$ & $31.8 \pm 1.0$ \\
\hline Forearm & $25.6 \pm 1.2$ & $25.7 \pm 1.3$ & $24.1 \pm 1.3$ & $24.0 \pm 1.2$ & $25.4 \pm 1.3$ & $25.4 \pm 1.3$ & $25.5 \pm 1.3$ & $25.5 \pm 1.3$ \\
\hline Hand & $18.3 \pm 0.9$ & $18.5 \pm 0.9$ & $18.2 \pm 0.9$ & $18.0 \pm 1.0$ & $18.0 \pm 1.0$ & $18.1 \pm 0.8$ & $18.0 \pm 1.6$ & $17.8 \pm 1.8$ \\
\hline Thigh & $43.9 \pm 2.8$ & $44.0 \pm 2.7$ & $41.7 \pm 1.6$ & $41.7 \pm 1.6$ & $43.4 \pm 2.3$ & $43.5 \pm 2.3$ & $42.0 \pm 2.0$ & $42.9 \pm 2.2$ \\
\hline Calf & $42.5 \pm 2.4$ & $42.7 \pm 2.2$ & $40.6 \pm 1.6$ & $40.6 \pm 1.7$ & $40.6 \pm 1.6$ & $40.7 \pm 1.7$ & $41.1 \pm 1.6$ & $41.0 \pm 1.6$ \\
\hline \multicolumn{9}{|l|}{ Girth $(\mathrm{cm})$} \\
\hline Upper arm & $28.8 \pm 1.7$ & $28.9 \pm 1.5$ & $24.8 \pm 1.8$ & $23.9 \pm 1.4 * *$ & $30.6 \pm 1.7$ & $30.4 \pm 1.5$ & $27.2 \pm 1.9$ & $26.7 \pm 2.0 * *$ \\
\hline Forearm & $26.4 \pm 1.1$ & $25.7 \pm 1.2 * * *$ & $24.7 \pm 1.6$ & $22.5 \pm 1.6 * * *$ & $27.8 \pm 1.2$ & $27.6 \pm 1.2$ & $24.3 \pm 1.3$ & $23.6 \pm 1.1 * * *$ \\
\hline Thigh & $56.5 \pm 1.8$ & $56.7 \pm 1.6$ & $49.3 \pm 3.6$ & $49.3 \pm 3.6$ & $56.6 \pm 3.1$ & $56.8 \pm 2.7$ & $51.5 \pm 3.2$ & $51.4 \pm 3.3$ \\
\hline Calf & $39.1 \pm 1.3$ & $38.9 \pm 1.4$ & $35.2 \pm 2.7$ & $36.0 \pm 3.1$ & $38.5 \pm 1.8$ & $38.1 \pm 1.5$ * & $37.2 \pm 1.7$ & $37.2 \pm 1.7$ \\
\hline
\end{tabular}

Mean \pm SD. D, dominant; ND, non-dominant. PG, Pitchers; TG, Tennis players; BG, Batters; CG, Controls. ${ }^{*} \mathrm{p}<0.05,{ }^{* *} \mathrm{p}<0.01,{ }^{* * *} \mathrm{p}<0.001$, Significantly different from non-dominant side. 
Table 3. Comparison of muscle thickness between dominant and non-dominant sides.

\begin{tabular}{|c|c|c|c|c|c|c|c|c|c|c|}
\hline & \multicolumn{2}{|c|}{ PG } & \multicolumn{2}{|c|}{$\mathrm{TG}$} & & \multicolumn{2}{|c|}{$\mathrm{BG}$} & & \multicolumn{2}{|c|}{$\mathrm{CG}$} \\
\hline & $\mathrm{D}$ & $\mathrm{ND}$ & $\mathrm{D}$ & $\mathrm{ND}$ & & $\mathrm{D}$ & $\mathrm{ND}$ & & $\mathrm{D}$ & $\mathrm{ND}$ \\
\hline \multicolumn{11}{|l|}{ Muscle thickness (mm) } \\
\hline Forearm & $23.9 \pm 2.1$ & $22.9 \pm 1.8 *$ & $22.7 \pm 2.3$ & $20.7 \pm 1.7$ & $* * *$ & $26.7 \pm 2.1$ & $25.8 \pm 1.8$ & & $21.4 \pm 2.7$ & $21.2 \pm 2.3$ \\
\hline Anterior upper arm & $31.7 \pm 2.9$ & $31.6 \pm 2.7$ & $29.5 \pm 2.3$ & $28.0 \pm 3.3$ & $*$ & $34.6 \pm 4.0$ & $35.2 \pm 2.8$ & & $30.9 \pm 3.2$ & $30.3 \pm 3.5$ \\
\hline Posterior upper arm & $33.9 \pm 4.2$ & $33.3 \pm 3.6$ & $27.3 \pm 5.0$ & $25.3 \pm 4.2$ & $* * *$ & $34.3 \pm 5.3$ & $37.3 \pm 5.5$ & $*$ & $29.4 \pm 2.8$ & $27.9 \pm 2.5$ \\
\hline Subscapula & $31.6 \pm 5.4$ & $28.1 \pm 5.6 * * *$ & $23.1 \pm 3.7$ & $22.4 \pm 3.5$ & & $30.7 \pm 4.7$ & $29.5 \pm 4.8$ & $*$ & $27.7 \pm 5.7$ & $27.4 \pm 4.8$ \\
\hline Chest & $24.2 \pm 5.1$ & $22.2 \pm 4.5 * * *$ & $18.8 \pm 3.5$ & $16.1 \pm 2.8$ & $* * *$ & $26.4 \pm 4.4$ & $25.4 \pm 3.6$ & $*$ & $23.9 \pm 5.1$ & $23.1 \pm 4.4$ \\
\hline Abdomen & $17.5 \pm 2.3$ & $17.8 \pm 2.7$ & $13.8 \pm 1.6$ & $15.2 \pm 2.9$ & $* *$ & $17.5 \pm 1.5$ & $17.4 \pm 1.5$ & & $17.1 \pm 1.6$ & $17.2 \pm 1.9$ \\
\hline Lateral abdomen & $31.5 \pm 3.7$ & $33.5 \pm 3.7 *$ & $23.8 \pm 3.5$ & $26.4 \pm 4.3$ & $* * *$ & $30.3 \pm 3.4$ & $32.8 \pm 4.9$ & $* *$ & $28.3 \pm 3.8$ & $27.6 \pm 4.3$ \\
\hline -External oblique & $11.0 \pm 1.3$ & $11.4 \pm 1.8$ & $8.6 \pm 1.2$ & $9.3 \pm 1.7$ & * & $10.5 \pm 1.7$ & $10.7 \pm 2.1$ & & $10.0 \pm 1.8$ & $9.6 \pm 1.7$ \\
\hline - Internal oblique & $15.6 \pm 2.3$ & $17.1 \pm 2.1$ * & $11.1 \pm 1.9$ & $12.5 \pm 2.3$ & $* * *$ & $14.9 \pm 2.2$ & $16.5 \pm 3.1$ & $* * *$ & $13.4 \pm 1.5$ & $13.2 \pm 2.4$ \\
\hline -Transverse abdominis & $5.4 \pm 0.9$ & $5.7 \pm 1.1$ & $4.2 \pm 1.1$ & $4.7 \pm 1.2$ & $*$ & $5.2 \pm 1.0$ & $6.0 \pm 1.1$ & * & $4.7 \pm 0.5$ & $4.9 \pm 0.7$ \\
\hline Anterior thigh & $61.8 \pm 3.8$ & $63.1 \pm 4.5$ & $53.3 \pm 6.7$ & $53.9 \pm 7.4$ & & $63.3 \pm 5.5$ & $62.4 \pm 4.7$ & & $53.9 \pm 4.4$ & $54.8 \pm 5.1$ \\
\hline Posterior thigh & $73.9 \pm 4.7$ & $73.6 \pm 4.5$ & $63.9 \pm 5.6$ & $63.3 \pm 5.7$ & & $72.3 \pm 6.1$ & $73.5 \pm 5.7$ & & $68.3 \pm 8.4$ & $67.3 \pm 7.5$ \\
\hline Anterior lower leg & $31.8 \pm 2.2$ & $31.8 \pm 2.1$ & $30.2 \pm 2.3$ & $29.7 \pm 2.7$ & & $31.9 \pm 1.8$ & $31.9 \pm 2.4$ & & $29.9 \pm 2.2$ & $29.8 \pm 2.4$ \\
\hline Posterior lower leg & $75.6 \pm 3.8$ & $75.3 \pm 4.1$ & $67.6 \pm 6.5$ & $68.5 \pm 7.0$ & & $74.8 \pm 4.7$ & $75.2 \pm 4.3$ & & $74.5 \pm 4.2$ & $73.6 \pm 4.1$ \\
\hline
\end{tabular}

Mean \pm SD. D, dominant; ND, non-dominant. PG, Pitchers; TG, Tennis players; BG, Batters; CG, Controls. ${ }^{*} \mathrm{p}<0.05,{ }^{* *} \mathrm{p}<0.01,{ }^{* * *} \mathrm{p}<0.001$, Significantly different from non-dominant side.

に，前腕部や上腕部の筋厚には，一側優位性が示されな かったものと考えられる，一方，野球投手の前腕部，テ 二ス選手の前腕部, 上腕前部, 上腕後部では利き側が高 い值を示し，野球打者の上腕後部では非利き側が高い值 を示した，先行研究において，テニス選手では上腕部の 伸筋，屈筋に利き側の優位性が見られることが報告され ている20)，テニス競技に扔いてラケットを加速するため に使われる上肢の筋は, フォアハンドストロークでは上 腕三頭筋と橈側手根屈筋, サーブでは円回内筋と上腕三 頭筋であり, フォアハンドストロークの加速局面では上 腕二頭筋に高い筋活動が見られ 孔 $^{28,34)}$ ，肩関節の水平屈曲 や肩や肘の安定化に貢献していると考えられている。こ のことから，テニス選手の上肢では，サーブやストロー ク動作中に高い筋活動を示寸筋群に特異的な発達が示さ れたものと考えられる。これに対して, 野球の投球動作 では，ボールへ伝えられるパワーのほとんどが体幹や肩 関節の筋群により生み出されたエネルギーの転移により もたらされる関節間力パワーに起因しており, 肘関節や 手関節によるトルク発揮は高くない35)。このため, 野球 の投球動作とテニスのサーブやストローク動作は，いず れも片腕で行われる類似した動作であるが，打具を用い るテニス選手では, 肩や肘などの関節の安定化のために, 上腕の屈筋群に高い筋活動が示されることが, テニス選 手のみに上腕前部, 後部に一側優位性が示されたことに 関係していると考えられる。また，上腕後部の筋厚にお いて, 主に片腕で打撃動作を行うテニス選手では, 利き
側に優位性が示されたのに対して, 両腕で打撃動作を行 う野球打者では，非利き側に優位性が示された。サーブ やフォアハンドストロークは右利きのテニス選手では野 球打者と同じ左回旋であるが，バックハンドストローク では逆の右回旋の動作が見られる。ゲーム中の両動作の 使用頻度はさまざまな要因が関係するため一定ではない が，右利きの選手はサーブが必ず左回転で行われること や，フォアハンドストロークがバックハンドストローク よりも頻繁に使用されることなどから，これまでの一側 優位性に関する研究では左回旋を行う競技者として扱 われている22-24)。本研究においてもテニス選手と野球打 者はともに左回旋の打動作を伴う共通した特徵を持つ競 技者としているが，野球打者が両腕でスイング動作を行 うのに対して，テニス選手は主に片腕でスイング動作を 行うという運動様式の違いが見られる。野球のバッティ ングでは, バットを握ったときに下に位置するボトムハ ンド（右打者の左腕）は引き手としてスイングをリード し，バットをコントロールする役割があり，上に位置す るトップハンド（右打者の右腕）は押し手として衝撃に 負けないでボールを受ける役割があるとされる ${ }^{36)}$. バッ ティング動作の筋電図学的研究に扔いてボトムハンド （非利き側）の上腕三頭筋には顕著な筋活動が認められ, その筋活動はスイング動作初期において最も顕著である ことから ${ }^{37.38)}$ ，バットを加速させるための主働筋として 位置付けられている。同じ左回旋の打撃動作ではあるも のの, テニスのフォアハンドストロークでは利き腕の貢 
Dominant $/$ Non-dominant $\times 100(\%)$
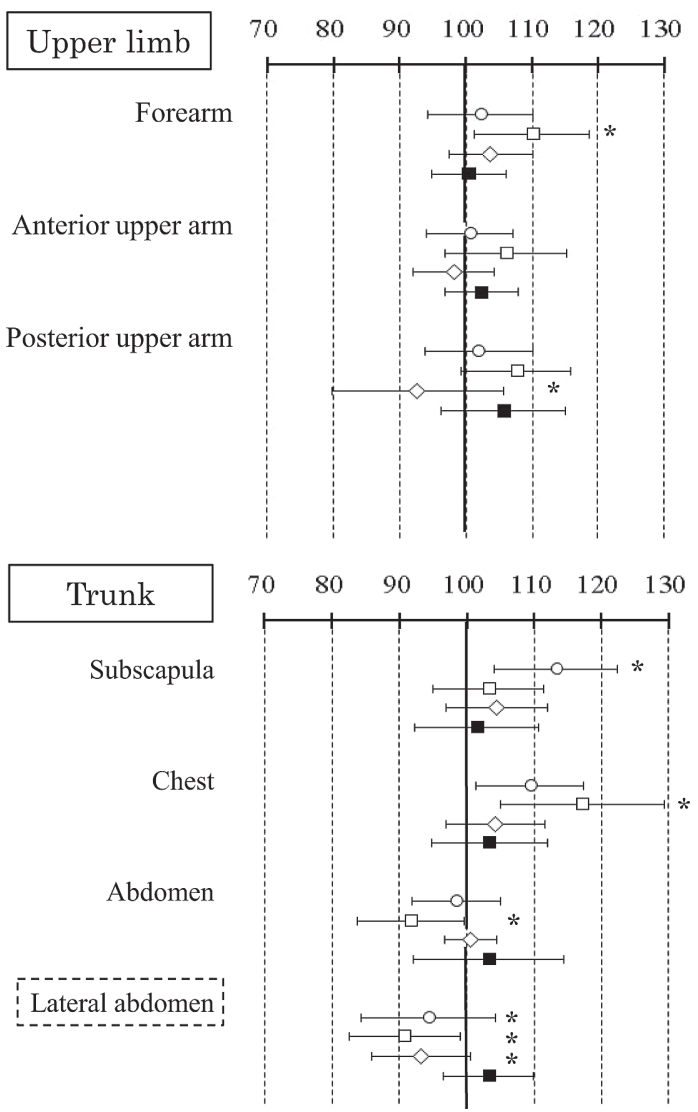

Dominant $/$ Non-dominant $\times 100(\%)$
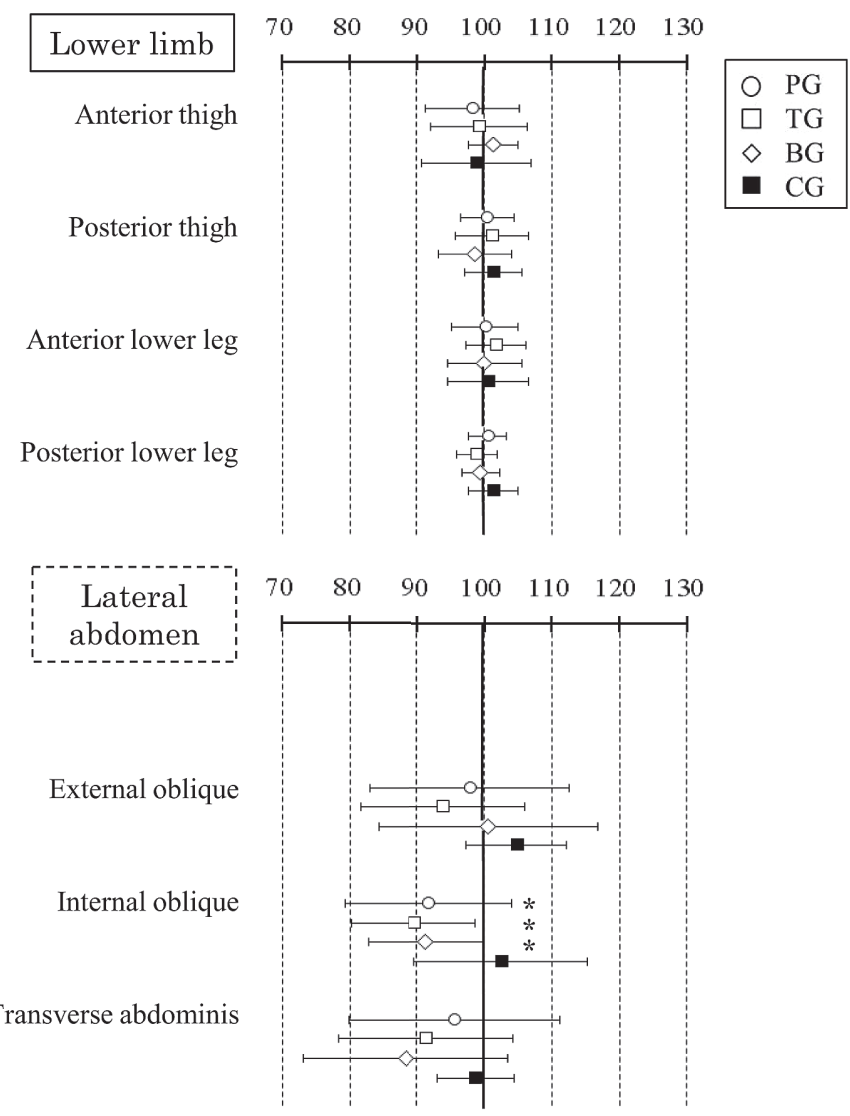

Fig. 2 Comparison of asymmetries of muscle thickness in each group. PG, Pitchers; TG, Tennis players; BG, Batters; CG, Controls. ${ }^{*} \mathrm{p}<0.05$ Significant differences compared to controls.

献が高いのに対して, 野球のバッティングでは非利き側 の貢献が高いことにより ${ }^{35,36)}$ ，テニス選手とは反対の非 利き腕に一側優位性が示されたものと考えられる.

体幹部の筋量については, 一般成人を対象とした研究 において，利き側と非利き側では差が見られないことが 報告されている ${ }^{14,21,24)}$ 。本研究においても, 対照群の体 幹部では，全ての測定部位において，利き側と非利き側 の間に筋厚の差は示されなかった。 このことから, 陸上 短距離選手のように，利き側のみを頻繁に使用しない競 技者の場合，体幹部に筋厚の一側優位性は示されないも のと考えられる。一方, 野球投手と野球打者の肩甲下部 と胸部, テニス選手の胸部では利き側が優位性を示した のに対して, 野球投手と野球打者の側腹部, テニス選手 の前腹部と側腹部では非利き側が優位性を示し, 体幹の 上部と下部では, 筋厚の優位性が異なる方向に見られた。 体幹上部の大胸筋は鎖骨, 胸骨, 肋骨, 外腹斜筋膜に起 始を持ち, 広背筋は胸椎, 胸腰筋膜, 腸骨, 胁骨に起始 を持つ ${ }^{1)}$ 。いずれも上腕骨に停止して体幹部と上肢を結 ぶ筋であり，野球の投球やテニスのサーブ動作において 高い筋活動を示し ${ }^{32}$, 主に肩関節の内旋, 内転作用を担っ
ている. 肩関節筋力に関する研究においても, 野球投手 やテニス選手は利き側の内旋筋力が非利き側に対して高 い傾向が見られ (5, $^{5)}$, 利き側の優位性は, 肩関節の内旋 筋群に高い水準の筋活動が示される, 投動作や打動作を 反復したことに対する筋の適応であると考えられてい る。また，野球打者の場合にも，肩関節内旋筋力は利き 側が高い值を示すことが報告されているが3)，打動作の 反復だけではなく, 送球動作の反復が影響している可能 性も考えられる。また, 体幹下部では, 前腹部の腹直筋 が体幹を屈曲する作用, 側腹部の外腹斜筋が対側への回 旋や側屈, 屈曲作用, 内腹斜筋が同側への回旋や側屈作 用，腹横筋が同側への回旋と腹腔内圧を高める作用を持 $\supset^{1,29)}$. 本研究の対象は投動作や打動作が左回旋となる 競技者であり，体幹の捻転には左側（非利き側）の内腹 斜筋, 右側 (利き側) の外腹斜筋が共同して働く. 本研 究において野球投手, テニス選手, 野球打者の内腹斜筋 はいずれも非利き側の筋厚が高い值を示した。同様の結 果はテニス選手 ${ }^{21)}$ でも報告されており，野球のピッチン グやバッティング, テニスのサーブやストロークが非利 き側への回旋を伴う動作であることや, 内腹斜筋が非利 
き側への体幹の回旋に押いて大きなトルクを発揮するこ とから ${ }^{29)}$ ，これらの動作を反復することが影響している と考えられる。また，テニス選手では外腹斜筋の筋厚は 利き側ではなく，非利き側において高い值を示した，外 腹斜筋は筋の部位と走行方向により作用が異なり, 白線 に停止する上部線維は体幹の回旋作用に貢献し, 恥骨に 停止する中部線維や，鼡径部に停止する下部線維は同側 への側屈に貢献する ${ }^{1,39)}$. 本研究における外腹斜筋の測 定部位は中部線維であり, 体幹の側屈に貢献する部位に 相当する.テニスのサーブ動作では, より高い打点でボー ルを打つことが求められることから，大きく体幹を左側 屈した姿勢を強いられ，非利き側の筋厚の増大に影響し た可能性も考えられる。

下肢の筋量についても, 一般成人の下肢筋群には, 利 き側と非利き側の間に差は見られないことが報告されて いる ${ }^{14,23)}$. 本研究の対照群に打いても同様の結果が得ら れたことから，利き側の上肢のみを頻繁に使用しない競 技者では, 下肢の筋厚に扔いても一側優位性は示されな いと考えられる。 また, 大腿前部, 大腿後部, 下腿前部, 下腿後部の筋厚では野球投手, テニ久選手, 野球打者に おいても両側間の差は示されなかった。 下肢の筋厚や筋 断面積については, 野球, 陸上投擲, テニス, バレーボー ル, バドミントンの選手を対象に両側を比較した研究が 見られるが ${ }^{14,15,17,23,25,26)}$ ，その多くは本研究と同様に，大 腿部, 下腿部の筋厚において両側間に差が見られないと する報告である。しかし，バドミントン選手では，利き 側の大殿筋や大腿部 (内転筋群) の筋横断面積が大きい ことが報告されており ${ }^{25,26)}$ ，その原因については，シャ トル捕捉動作に見られる股関節の役割の非対称性や，臀 部に高い筋活動がみられる股関節外転, 外旋位の姿勢が 影響していると推察されている. 本研究の対象である野 球投手の投球動作に打ける軸脚（利き側）の役割は股関 節伸展卜ルクや股関節内転トルクの発揮により下胴を回 転させ, 体幹の捻りを生み出すことであり, 踏込脚（非 利き側）の役割は伸展トルクの発揮により体幹を支持す るとともに, 股関節内転卜ルクを発揮して下胴の前回旋 を維持することである ${ }^{40)}$. また，打撃動作についても投 球動作との類似性が指摘されて抢り ${ }^{31}$, 機能面に扔ける 股関節伸筋や内転筋の役割と重要性は明らかになってき た. しかし, 先行研究に打いても, 野球選手やテニス選 手の大腿四頭筋，ハムストリングス，大殿筋の筋量に は一側優位性が見られず14,23)，野球のピッチングやバッ ティング，テニスのサーブやストロークの動作の反復に は，これらの筋の一側優位性をもたらす効果があるとは 考えにくい. しかし，バドミントン選手の一側優位性が 報告された大殿筋や股関節内転筋群については, 本研究 では測定対象としなかったことから，両側間の筋厚に差 の有無について明らかにすることはできなかった。
本研究の被験者はいずれも競技種目のトレーニングに 加えて、レジスタンストレーニングを実施していた。 こ れまでのスポーツ選手に見られる筋量の一側優位性に関 する研究に执いて, レジスタンストレーニング実施の有 無については考慮されて抢らず，その影響の程度は明ら かではない. しかし, 片側性の筋力発揮を強調するプロ グラムは実施されて扔らず，レジスタンストレーニング が競技に特異的な動作の反復によって生じる一側優位性 を顕著にした可能性は低いと考えられる。一方，レジス タンストレーニングが一側優位性を打ち消す方向に作用 した可能性も否定できないことから，利き側または非利 き側に示された筋厚の一側優位性は, 投動作や打動作を 反復することによって, 顕著に示される筋発達の特徵で あると考えられる。

本研究では利き側の非利き側に対する比率 (D/ND比 率）を対照群と比較することにより，野球投手，テニス 選手, 野球打者において, 一側優位性の大きさが対照群 を上回る部位の特定を試みた。野球投手，テニ久選手， 野球打者では側腹部とその構成筋である内腹斜筋のD／ $\mathrm{ND}$ 比率が対照群に対して有意に低い值を示し, 非利き 側において，利き側の影響で生じるよりも大きな一側優 位性が示された。被験者がいずれも体幹の捻転運動を反 復する競技者であることや, 内腹斜筋が同側への回旋に 作用する筋であることから，側腹筋（内腹斜筋）の優位 性は, 先行研究 ${ }^{15,21)}$ と同様に, 投動作や打動作に対する 筋の適応やトレーニング効果を示すものと考えられる. また, 本研究では野球投手や野球打者と比べて, 競技歴 が有意に短いテニス選手においても, 側腹部では同様の 一側優位性が示された。筋の一側優位性の形成過程や, 競技歴の影響については明らかではないが, 肩関節の内 旋筋力や肘関節の伸展筋力に関する研究では, 12 歳 17 歳のジュニアのテニス選手にも利き側の優位性が示され ていることから ${ }^{10)}$, 筋力や筋量の一側優位性は競技開始 後，比較的早期に形成されるものと考えらえる．

側腹部以外では，野球投手の肩甲下部，テニス選手の 前腕部や胸部では $\mathrm{D} / \mathrm{ND}$ 比率が対照群よりも高く, 利き 側に優位性が示され, 野球打者の上腕後部やテニス選手 の前腹部では $\mathrm{D} / \mathrm{ND}$ 比率が対照群よりも低く, 非利き側 に優位性が示された。側腹部の一側優位性が野球投手, テニス選手, 野球打者に共通するのに対し, これらの筋 では競技者別に異なる一側優位性が示された，野球投手 の肩甲骨下部は広背筋，テニス選手の前腕部は手関節や 手指の屈筋と円回内筋, 胸部は大胸筋, 前腹部は腹直 筋, 野球打者の上腕後部は上腕三頭筋に相当するもので あり，いずれもピッチング動作やテニスのサーブ及びス トローク動作，バッティング動作に打いて高い筋活動を 示すことが報告されている30,32,34,37,38). これらは主に上 肢の働きに関連した筋であることから，対照群に対する 

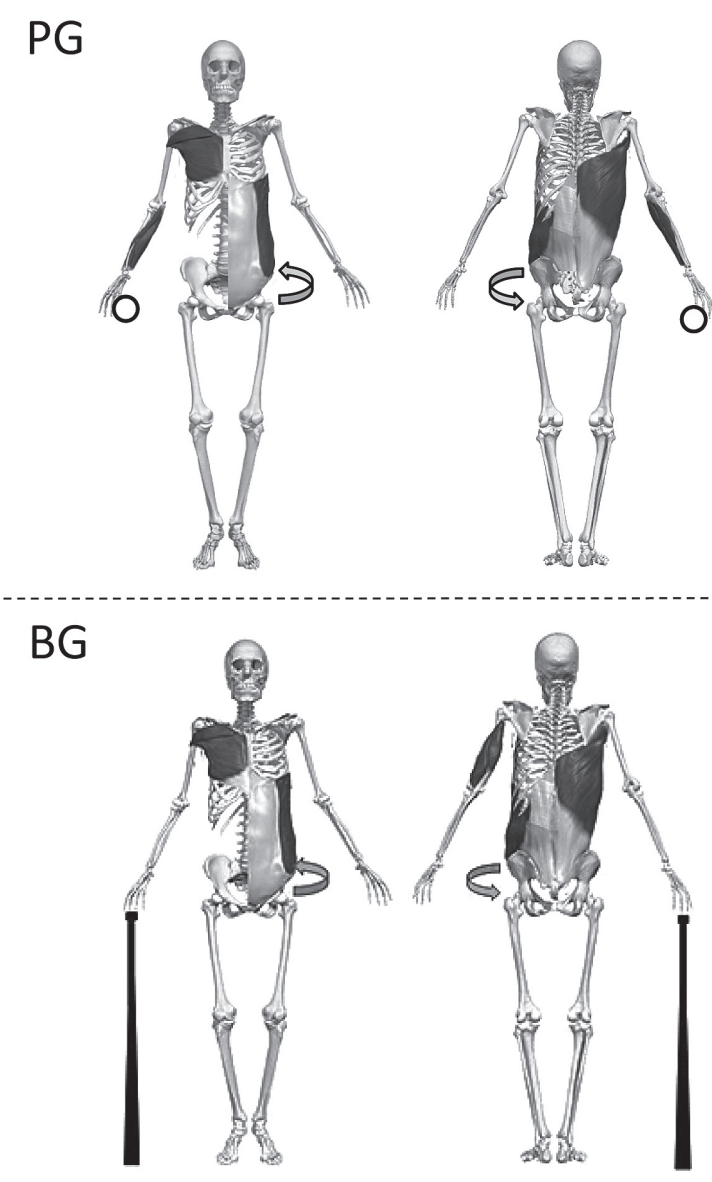

TG
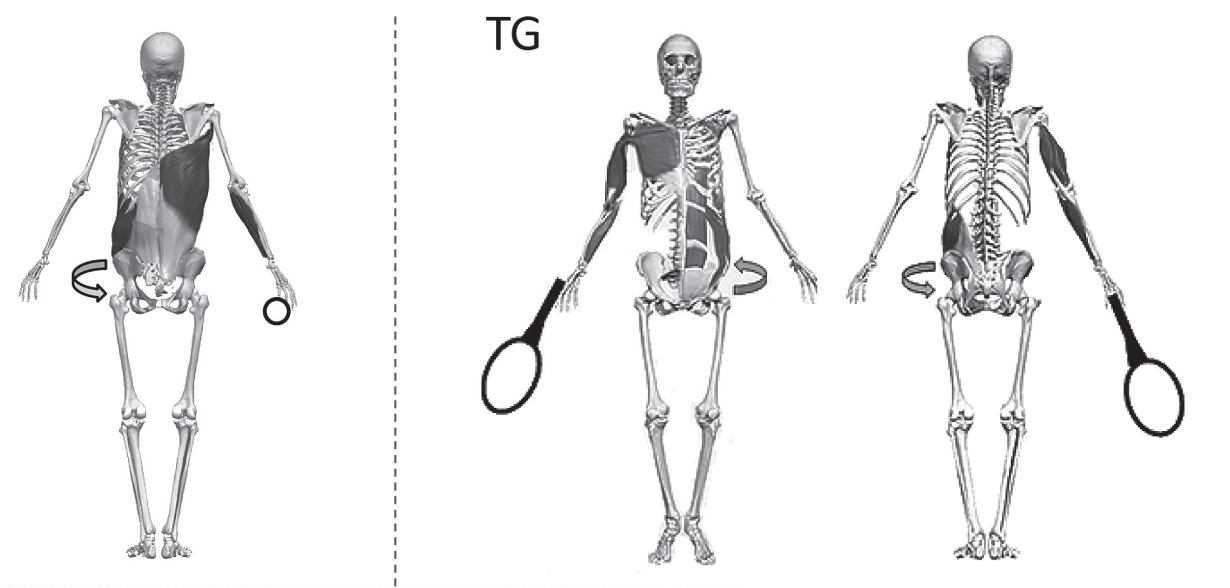

\section{CG}

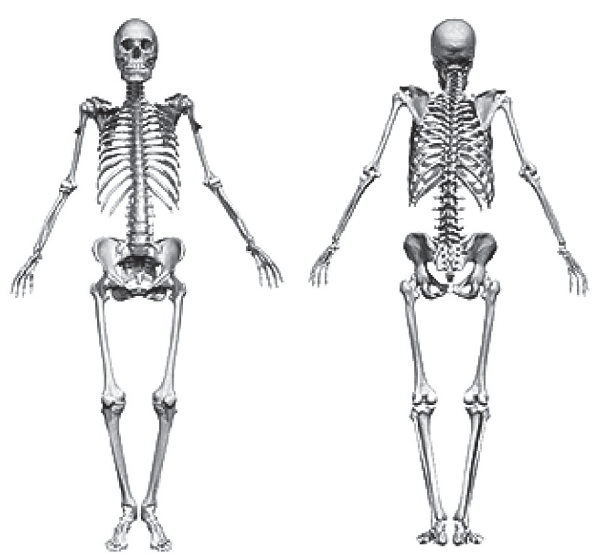

Fig. 3 Muscles that are thicker than the those on the other side in each group. PG, Pitchers; TG, Tennis players; BG, Batters; CG, Controls.

$\mathrm{D} / \mathrm{ND}$ 比率の差は，競技によって異なる上肢の動作の特 異性を反映したものと考えられる.

\section{結 論}

本研究では野球投手, テニス選手, 野球打者と対照群 （短距離走選手）の 4 群について, 全身11部位の筋厚測 定を行い，利き側と非利き側の筋厚を比較することによ り以下のような結論を得た。

1. 野球投手の前腕部, 肩甲下部, 胸部, テニス選手の 前腕部，上腕前部，上腕後部，胸部，野球打者群の 肩甲下部，胸部では利き側が非利き側に対して有意 に高い值を示した。

2. 野球投手の側腹部, テニス選手の前腹部, 側腹部, 野球打者の側腹部では非利き側が利き側に対して有 意に高い值を示した。

3. 非利き側に対する利き側の筋厚の比率 ( $\mathrm{D} / \mathrm{ND}$ 比率) では，野球投手，テニス選手，野球打者はいずれも 側腹部，およびその構成筋である内腹斜筋の筋厚に おいて対照群に対して有意に低い值を示した。

以上のことから，投動作や打動作を伴う競技者である 野球投手，テニ久選手，野球打者では体幹下部の筋厚に
おいて非利き側の側腹筋（内腹斜筋）に一側優位性が見 られるが，下肢では筋厚の一側優位性は見られないこと が共通点として示された。また，上肢や体幹上部の筋厚 の一側優位性には，投動作や打動作におけるスイング様 式による特異性が見られることが示唆された。

\section{参考文献}

1）森 於蒬, 小川鼎三, 大内 弘, 森 富. 分担解剖学 I, 第11 版, 金原出版, 東京, 2002 .

2）木村邦彦, 浅枝澄子：ヒトの四肢の一側優位性について, 人類誌, 82 : 189-207, 1974.

3) Brown LP, Niehues SL, Harrah A, Yavorsky P, Hirshman HP. Upper extremity range of motion and isokinetic strength of the internal and external shoulder rotators in major league baseball players. Am J Sports Med 16: 577-585, 1988.

4) Wilk KE, Andrews JR, Arrigo CA, Keirns MA, Erber DJ. The strength characteristics of internal and external rotator muscles in professional baseball pitchers. Am J Sports Med 21: 61-66, 1993.

5) Ellenbecker TS, Mattalino AJ. Concentric isokinetic shoulder internal and external rotation strength in professional baseball pitchers. J Orthop Sports Phys 
Ther 25: 323-328, 1997.

6) Ellenbecker T, Roeters E.P. Age specific isokinetic glenohumeral internal and external rotation strength in elite junior tennis players. J Sci Med Sport 6: 63-70, 2003.

7) Wang H, Macfarlane A, Cochrane T. Isokinetic performance and shoulder mobility in elite volleyball athletes from the United Kingdom. Br J Sports Med 34: 39-43, 2000.

8) Silva RT, Gracitelli GC, Saccol MF, Laurino CF, Silva AC, Braga-Silva JL. Shoulder strength profile in elite junior tennis players: horizontal adduction and abduction isokinetic evaluation. Br J Sports Med 40: 513517, 2006.

9) Ellenbecker T, Roetert EP. Isokinetic profile of elbow flexion and extension strength in elite junior tennis players. J Orthop Sports Phys Ther 33: 79-84, 2003.

10) Laudner KG, Wilson JT, Meister K. Elbow isokinetic strength characteristics among collegiate baseball players. Phys Ther Sport 13: 97-100, 2012.

11) Ellenbecker TS, Roetert EP, Riewald S. Isokinetic profile of wrist and forearm strength in elite female junior tennis players. Br J Sports Med 40: 411-414, 2006.

12）後藤篤志, 大川昌宏：大学軟式野球選手の体幹筋の特 徵に関する研究, NITTAI Sports Training Journal 1: 19-23, 2005.

13) Hirano $Y$, Ikegawa S. Laterality in upper limb composition and maximal isometric strength of elbow joint of baseball players. 東京大学教養学部体育学紀要, 21 : 20-24, 1987.

14）角田直也, 田中重陽, 石塚信之, 青山利春, 岡田雅次, 西 山一行：投動作パフォーマンスに及ぼす筋形態及び機 能的特性, 国士舘大学体育研究所報, 21: 135-140, 2003.

15）長谷川伸, 小野高志: 野球投手の筋厚の非対称性とボー ルスピードの関係, 体力科学, 61: 227-235, 2012.

16）長谷川伸, 館 俊樹, 斎藤恵一, 王 力群, 加藤清忠：野球 投手の回旋腱板筋（rotator cuff muscles）と三角筋の MRI法による筋量分析とその筋力特性, 体力科学, 53: 483-492, 2004.

17）島野敬四郎, 内田智子, 安藤佳代子, 高山伸也, 須田憲司, 湯浅景元 : 女性投てき選手の筋厚と筋力, 中京大学体 育学論叢, 39: 107-112, 1997.

18）大川昌宏, 菅原 勲, 櫻井忠義：やり投げ選手の体幹筋横 断面積の左右差および競技記録との関係, トレーニン グ科学, 17: 281-286, 2005.

19) Sanchis-Moysi J, Idoate F, Serrano-Sanchez JA, Dorado C, Calbet JAL. Muscle Hypertrophy in Prepubescent Tennis Players: A Segmentation MRI Study. Polosone 7: 1-7, 2012.

20）三浦 朗, 友末亮三, 池川繁樹, 平野裕一, 金久博昭, 福永 哲夫：ボート・テニス・野球選手の上腕における筋 力および組成の左右差, トレーニング科学, 6: 95-100, 1994.

21）久保田 潤, 奥村幸治, 鳥居 俊, 福林 徹 : 大学テニス選 手における腹筋群の形態的特徴, 日本臨床スポーツ医
学会誌, 17: 30-34, 2009.

22) Sanchis-Moysi J, Idoate F, Dorado C, Alayón S, Calbet JA. Large asymmetric hypertrophy of rectus abdominis muscle in professional tennis players. PLOS One 5: e15858, 2010.

23) Sanchis-Moysi J, Idoate F, Izquierdo M, Calbet JA, Dorado C. Iliopsoas and gluteal muscles are asymmetric in tennis players but not in soccer players. PLOS One 6: 1-10, 2011.

24）村松正隆, 星川佳広, 飯田朝美, 井伊希美, 中嶋由晴 : 高 校生スポーツ選手の体幹筋群の筋サイズ - 性差と競技 種目差の検討 - , 体育学研究, 55: 577-90, 2010.

25）村松正隆, 星川佳広, 飯田朝美, 井伊希美, 中嶋由晴 : 高 校生スポーツ選手の大殿筋断面積の競技種目特性, 体 育学研究, 55: 193-201, 2010.

26）星川佳広, 飯田朝美, 村松正隆：高校生スポーツ選手の 大腿部筋断面積の性差と競技種目差, トレーニング科 学, 18: 375-386, 2006.

27）桜井伸二. 投げる科学, 初版, 大修館書店, 東京, 1992.

28）平野裕一. 打つ科学, 初版, 大修館書店, 東京, 1992.

29）大久保 雄, 金岡恒治 : 体幹の捻転動作の医学的基礎, バ イオメカニクス研究, 13: 125-129, 2009.

30）西㝨秀嗣：表面笳電図による投・打に関する類似動作 の分析, 北海道大学教育学部紀要, 35: 183-195, 1980.

31）宮西智久：野球の投・打動作の体幹捻転研究-SSC理 論に着目してー, バイオメカニクス研究, 13: 149-169, 2009.

32) Escamilla R.F, Andrews J.R. Shoulder muscle recruitment patterns and related biomechanics during upper extremity sports. Sports Med 39: 569-590, 2009.

33) Abe T, Kondo M, Kawakami Y, and Fukunaga T. Prediction equation for body composition of Japanese adults by B-mode ultrasound. Am J Human Biol 6: 161-170, 1994.

34) Morris M, Jobe F.W, Perry J, Pink M, Healy B.S. Electromyographic analysis of elbow function in tennis players. Am J Sports Med 17: 241-247, 1989.

35）宮西智久, 藤井範久, 阿江通良, 功力靖雄, 岡田守彦 : 野 球の投球動作における体幹および投球腕の力学的エネ ルギーフローに関する 3 次元解析, 体力科学, 46: 55-68, 1997.

36）土橋恵秀, 小山田良治, 小田伸午. 野球選手なら知って おきたい「からだ」のこと一打撃編, 大修館書店, 東京, 16-55, 2009.

37) Kitzman R.W. Baseball: Electromyographic study of batting swing. The Resarch Quartely 35: 166-178, 1963.

38) Shaffer B, Jobe F.W, Pink M, Perry J. Baseball batting. An electromyographic study. Clin Orthop Relat Res 292: 285-293, 1993.

39) Myers T.W (松下松雄訳), アナトミー・トレイン, 初版, 医学書院, 東京, 25-176, 2009.

40）島田一志, 阿江通良, 藤井範久, 結城匡啓: 野球のピッ チング動作における体幹および下肢の役割に関するバ イオメカニクス的研究, バイオメカニクス研究, 4: 4760, 2000 . 